\title{
AS CONTRADIÇÕES DO CERCEAMENTO DAS POLÍTICAS PÚBLICAS PARA A EDUCAÇÃO DO CAMPO EM TRÊS LAGOAS (MS): Escola Estadual Afonso Francisco Xavier Trannin e Escola Municipal Profa. Elma Garcia Lata Batista
}

\author{
LAS CONTRADICCIONES DE LA REDUCCIÓN DE LAS \\ POLÍTICAS PÚBLICAS PARA LA EDUCACIÓN DEL CAMPO EN \\ TRÊS LAGOAS (MS): Escuela Afonso Francisco Xavier Trannin y \\ Escuela Municipal Profa. Elma Garcia Lata Batista
}

\begin{abstract}
Francielle Rodrigues de Macedo Sanches Universidade Federal de Mato Grosso do Sul. Mestranda em Geografia e Graduada em GeografiaLicenciatura/UFMS. Três Lagoas, MS, Brasil francielle.r.macedo@gmail.com
\end{abstract}

Sedeval Nardoque Universidade Federal de Mato Grosso do Sul. Professor Doutor em Geografia pela Universidade Estadual Paulista Júlio de Mesquita Filho, Câmpus de Rio Claro. Professor dos cursos de Graduação e de PósGraduação em Geografia da UFMS/Três Lagoas. Três Lagoas, MS, Brasil nardoque@hotmail.com

\section{Resumo}

Esse artigo é resultado de reflexões realizadas a partir do Grupo de Estudos TerraTerritório (Gett), vinculado ao Laboratório de Estudos Territoriais (Labet), e, também, da participação como integrante do Núcleo de Desenvolvimento Territorial do Território Rural do Bolsão (NEDET), da Universidade Federal de Mato Grosso do Sul (UFMS), envolvendo temas que permearam a questão agrária e a Educação do Campo. O município de Três Lagoas (MS) é o recorte espacial deste estudo, localizado no Território Rural do Bolsão, no Leste de Mato Grosso do Sul. No âmbito municipal três-lagoense, houve forte industrialização nos últimos anos e as escolas rurais tornaram-se alvos das empresas do setor de celulose, uma vez que as ações governamentais em territórios de grande concentração fundiária são praticamente diminutas. Portanto, o objetivo deste trabalho é analisar as políticas públicas e toda a sua articulação para efetivação de ações dos governos federal, estadual e municipal e se estão em consonância com os princípios norteadores e direitos da educação dos sujeitos do campo, na Escola Estadual Afonso Francisco Xavier Trannin (Distrito Arapuá) e na Escola Municipal Profa. Elma Garcia Lata Batista (Distrito de Garcias), situadas no município de Três Lagoas (MS).

Palavras-chaves: Educação do Campo. Políticas Públicas. Direitos. 


\section{Resumen}

Este artículo es el resultado de las reflexiones realizadas desde el grupo de estudios territoriales (GETT), vinculado al laboratorio de estudios territoriales (Labet) y así como la participación como integrante del Núcleo de Desarrolo Territorial Rural del Bolsão (NEDET) la Universidad Federal de Mato Grosso del Sur (UFMS), a partir de temas que permearon la cuestión agraria y la educación del campo. El municipio de Três Lagoas (MS) es el recorte espacial de este estudio, ubicado en el Terriorio Rural de Bolsão, al este de Mato Grosso de Sul. En el ámbito municipal três-lagoense, ha habido una fuerte industrualización en los últimos años y las escuelas rurales se han convertido en objectivos de empresas del sector de celulosa, ya que las acciones del gobierno en grandes territorios de concetracíon de tierra son practicamente diminutas. Por lo tanto, el objetivo de este estudio es el analizar las políticas públicas y también de su relación con acciones efectivas del gobierno: federal, estado y municipal y sí estan en linea con los principios fundamentales y los derechos de la educación de personas del campo, en la escuela estatal Alfonso Francisco Xavier Trannin (Arapuã Distrito) y en la escuela municipal, Prof. Elma García Can Batista (Distrito de Garcias) situada en el municipio de Três Lagoas (MS).

Palabras clave: Educación del Campo. Políticas Públicas. Derechos.

\section{Introdução}

A partir da década de 1980, com a ascensão dos movimentos sociais no campo, surgiu, com ações da Comissão Pastoral da Terra $(\mathrm{CPT})^{1}$, o Movimento dos Trabalhadores Rurais Sem Terra (MST). Nas ações dos movimentos sociais organizados no campo, houve demandas de educação para o povo do campo, sobretudo nos acampamentos de luta pela Reforma Agrária, no decorrer dos anos 1980 e 1990. Desta maneira, em 1997, houve mobilização de entidades governamentais e organizações dos movimentos sociais pensando-se na Educação do Campo, para pressionar o Estado a cumprir seu papel de provedor de direito, e "[...] construíram a 'Articulação Nacional Por Uma Educação Básica do Campo', com sede em Brasília." (ARROYO e FERNANDES, 1999, p.08). Assim, discutiram-se os seguintes pontos sobre a educação camponesa:

[...] 1 - Criação de um projeto para educação no meio rural - Por uma escola do campo.

2 - Produção de materiais didáticos voltados para a realidade da agricultura camponesa.

3 - Uma educação que valorize a vida no campo: uma escola com identidade própria.

4 - Uma pedagogia que se preocupe com todas as dimensões da vida, para promoção humana.

5 - Uma escola pública em todos os acampamentos e assentamentos. 
As contradições do cerceamento das políticas públicas para a educação do campo em Três Lagoas (MS):

Escola Estadual Afonso Francisco Xavier Trannin e

Escola Municipal Profa. Elma Garcia Lata Batista
Francielle Rodrigues de Macedo Sanches Sedeval Nardoque

6 - Uma gestão pedagógica da comunidade.

7 - Uma escola solidária com as pessoas e as organizações que tenham projetos de transformação social. (ARROYO e FERNANDES, 1999, p. $54)$.

Dessa reunião saíram algumas diretrizes de embasamento para outra mobilização prevista e acontecida em 2001. Não se pode deixar de ressaltar a importância do I Encontro Nacional das Educadoras e Educadores da Reforma Agrária (ENERA), em 1997: “[...] Nesse contexto, o ENERA foi um marco no setor da Educação do MST e, fora dele.” (LEMES, 2014, p. 103). Naquele encontro, traçaram-se as diretrizes para a criação do Programa Nacional de Educação na Reforma Agrária (PRONERA).

Resultante das pressões populares, promulgaram-se algumas leis no final da década de 1990. Nesse sentido Camacho (2013), ressalta-as:

[...] Constituição da República Federativa do Brasil, notadamente nos Art. 205, 206 e 207; o Plano Nacional de Educação - Lei n. ${ }^{\circ}$ 10.172, de 09/01/2001; a Lei de Diretrizes e Bases da Educação Nacional (Lei n. ${ }^{\circ}$ 9.394, de 20/12/1996), regulamentada pelo Decreto n. ${ }^{\circ}$ 2.208, de 17 de abril de 1997; o Decreto 7.352/2010, de 04 de novembro de 2010, que -Dispõe sobre a política de Educação do Campo e o Programa Nacional de Educação na Reforma Agrária, art. 11-18; as Resoluções do Conselho Nacional de Educação, relativas às normas para o Ensino Superior no Brasil, normas para os cursos Técnicos de Nível Médio e Graduação Tecnológica; a Resolução CNE/CEB n. ${ }^{\circ}$ 01/2002 - Diretrizes Operacionais para a Educação Básica nas Escolas do Campo; a Resolução CNE/CEB n. ${ }^{\circ}$ 01/2006 Paradigmas em Disputa na Educação do Campo 412 relativo à Pedagogia da Alternância (BRASIL/PRONERA, 2011). E acrescentamos, ainda, o Plano Nacional de Educação para o decênio 2011-2020 (PNE - 2011/2020). (CAMACHO, 2013, p. 411-412).

Essas leis representaram grandes passos para a Educação do Campo na elaboração de alguns projetos e programas para o campo para Mato Grosso do Sul, como o PRONERA, Saberes da Terra (ProJovem Campo na Universidade Federal da Grande Dourados/UFGD), Curso Normal Médio do Campo, Licenciatura em Ciências Sociais (na UFGD). A Universidade da Grande Dourados, foi a única com esses projetos comtemplada em Mato Grosso do Sul (LEMES, 2014), (CAMACHO, 2013).

Houve avanços (embora pequenos, mas irreversíveis) nesse desenrolar das políticas públicas criadas para a Educação do Campo. Havia necessidade de romper com a educação rural, pois sua característica tecnicista, além das situações precárias dos assentamentos, sem o Estado cumprir seu papel de provedor de direitos, prejudicam a 
As contradições do cerceamento das políticas públicas para a educação do campo em Três Lagoas (MS):

Escola Estadual Afonso Francisco Xavier Trannin e

Escola Municipal Profa. Elma Garcia Lata Batista

juventude e os adultos do campo, ambos mal instruídos e fragilizados pela dura vida de sobrevivência no campo, sucumbindo-os. (CALDART, 2012).

No âmbito municipal três-lagoense, houve, nos últimos anos, forte industrialização, principalmente, vinculada às empresas de papel e celulose, com extensos plantios de eucaliptos (cerca de 250 mil hectares), e as escolas rurais tornaram-se alvos de ações de tais empresas (Fíbria e Eldorado Brasil), pois, sobretudo, por meio de ações "pedagógicas" no interior das mesmas (LEMES, 2014), distanciam-se das vertentes pedagógicas preconizadas pelo PRONERA.

Entendendo a importância do tema, este trabalho tem como objetivo analisar os dispositivos legais para a Educação do Campo e como essa articulação entre entes federados, responsáveis pela garantia do direito a educação para todos, estão efetivando suas ações em duas escolas de Três Lagoas, a saber: Escola Estadual Afonso Xavier Trannin e Escola Municipal Profa. Elma Garcia Lata Batista.

\section{O território cercado das escolas estudadas}

Analisou-se, neste trabalho, duas escolas. A escolha se deve aos fatos de uma ser de administração municipal (Escola Municipal Profa. Elma Garcia Lata Batista (Figura 1)), e a outra, administração estadual (Escola Estadual Afonso Francisco Xavier Trannin (Figura 2)).

Figura 1 - Três Lagoas (MS), Distrito de Garcias: Escola Municipal Profa. Elma Garcia Lata Batista.

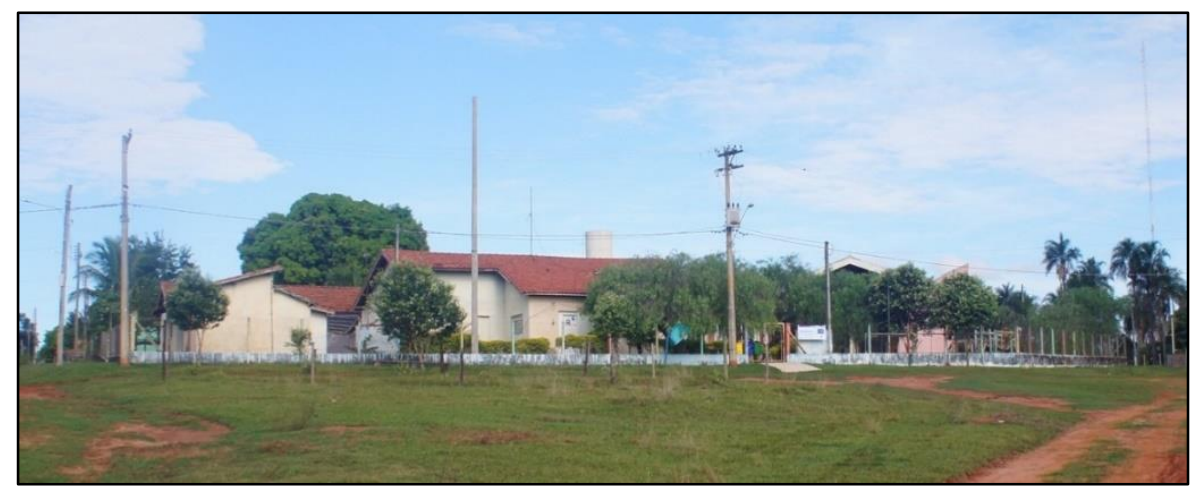

Fonte: Trabalho de campo.

Foto: MACEDO, F. R. 17 mai. 2016. 
As contradições do cerceamento das políticas públicas para a educação do campo em Três Lagoas (MS):

Escola Estadual Afonso Francisco Xavier Trannin e

Escola Municipal Profa. Elma Garcia Lata Batista
Francielle Rodrigues de Macedo Sanches Sedeval Nardoque

Figura 2 - Três Lagoas (MS), Distrito de Arapuá: Escola Estadual Afonso Xavier Trannin.

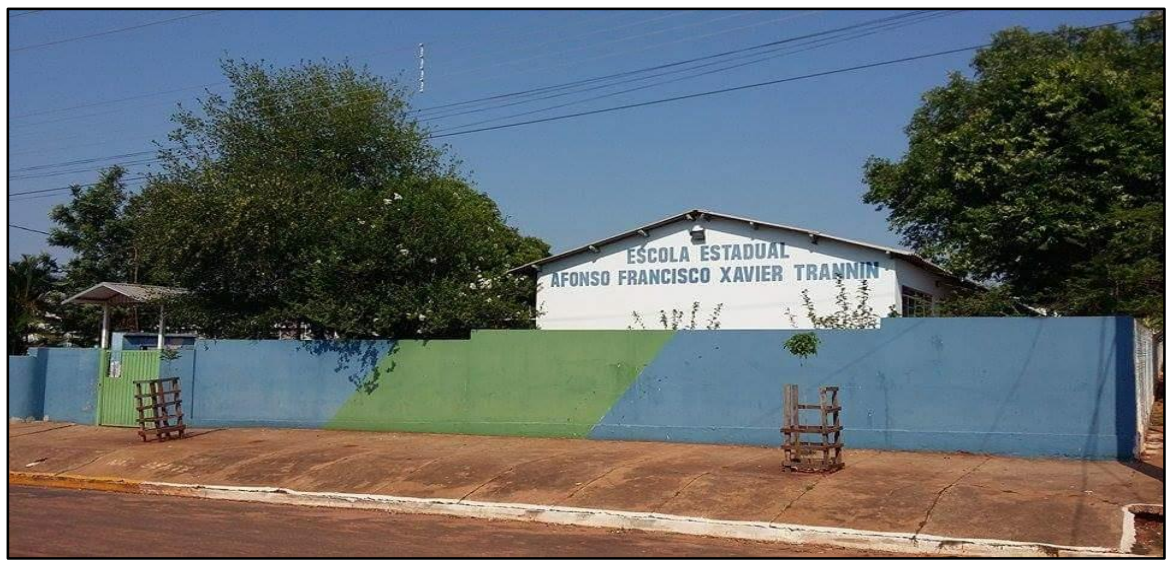

Fonte: Trabalho de campo.

Foto: MACEDO, F. R. 15 out. 2015.

Pontin e Nardoque (2016), Nardoque e Almeida (2015) e Kudlavicz (2011) explicam que o Território Rural do Bolsão (figura 3), teve forte influência em suas atividades econômicas pela pecuária e transformou a posse e o uso da terra com a chegada das empresas do setor de celulose (atraídas pela facilidade nos créditos; pela localização e estruturas construídas para dar suporte às mesmas, estrutura fundiária concentrada, etc). Em vários momentos históricos e econômicos em Mato Grosso do Sul as práticas de desenvolvimento e apropriação de terras ocorreram das mais diversas formas pelo capital (inclusive terras de índios, como no caso dos Ofaié em Brasilândia), por meio do esbulho (NARDOQUE e MELO, 2016) e da violência contra os pobres da terra.

Kudlavicz (2011, p. 23) afirma que os incentivos fiscais, dados aos latifundiários e às empresas para os plantios de eucalipto, incialmente, foram frutos de uma série de ações desenvolvimentistas neoliberais colocadas em ação a partir da década de 1960, a priori foram: "POLOCENTRO (Programa de Desenvolvimento dos Cerrados) e do PRODECER (Programa de Cooperação Nipo-Brasileira para Desenvolvimento dos Cerrados) [...] e o Fundo Constitucional para Financiamento do Centro-Oeste (FCO)", na década de 1990. A partir da segunda metade dos anos 2000 e início dos 2010, iniciaramse a implantação das indústrias de celulose e de papel em Três Lagoas. Assim,

Devido a influência da indústria de papel e celulose, houve a expansão de eucaliptais por vários municípios, principalmente em Três Lagoas, Selvíria e Água Clara, modificando o perfil agrário (reconcentração de terras) e agropecuário, diminuindo consequentemente as áreas tradicionais de pastagens e de produção de alimentos de origem vegetal. 
As contradições do cerceamento das políticas públicas para a educação do campo em Três Lagoas (MS):

Escola Estadual Afonso Francisco Xavier Trannin e

Escola Municipal Profa. Elma Garcia Lata Batista
Francielle Rodrigues de Macedo Sanches Sedeval Nardoque

Em todos os municípios do Território houve diminuição do efetivo bovino, principalmente em Três Lagoas, que, no período de 2005 e 2009 , teve seu rebanho reduzido de 938.008 para 754.126 cabeças. Por outro lado, a área ocupada com plantios de eucaliptos alcançou mais de 100 mil hectares no referido período. (NARDOQUE e ALMEIDA, 2015, p. 03 e 04).

Figura 3 - Mato Grosso do Sul: Território Rural do Bolsão
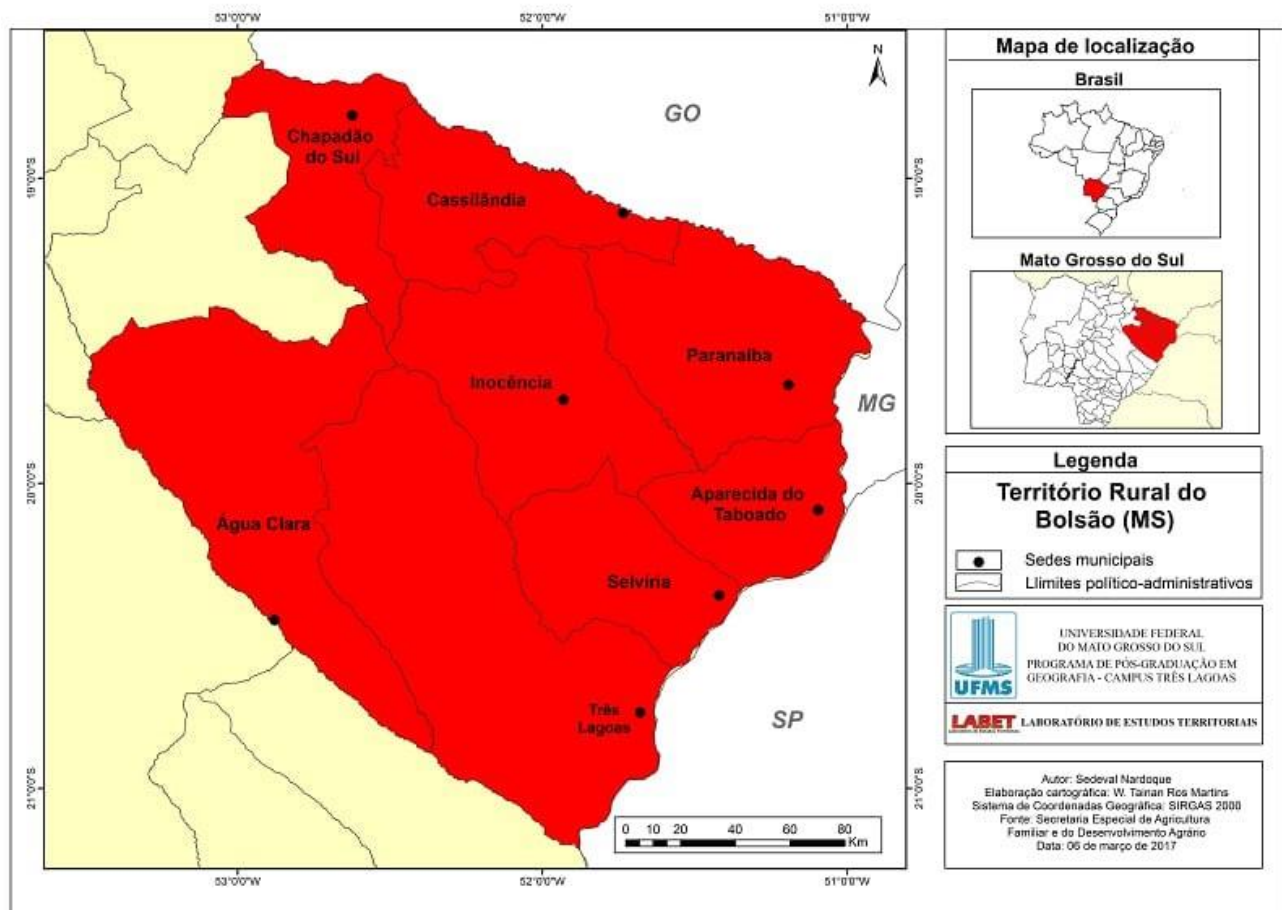

Fonte: Nardoque e Almeida (2015).

Para Nardoque (2016, p.273), o “[...] município de Três Lagoas é emblemático quanto à concentração fundiária [...]. Os estratos de até 200 hectares, mesmo representando $52,99 \%$ do total de imóveis rurais, totalizam apenas $0.63 \%$ da área ocupada. Por outro lado, os imóveis acima de 1.000 hectares somam 62,99 da área". A tabela 1 demonstra a concentração fundiária em Três Lagoas.

Tabela 1 - Três Lagoas (MS): estrutura fundiária - 2014.

\begin{tabular}{r|c|c|c|c}
\hline $\begin{array}{r}\text { Classe Área Total } \\
\text { (ha) }\end{array}$ & $\begin{array}{r}\mathbf{N}^{\circ} \\
\text { imóveis }\end{array}$ & $\mathbf{\%}$ & $\begin{array}{r}\text { Área Total } \\
\text { (ha) }\end{array}$ & \% \\
\hline menos 200 & 1.313 & $52,99 \%$ & $6.962,29$ & $0,63 \%$ \\
200 a menos de 500 & 545 & $22 \%$ & $179.707,19$ & $16,13 \%$ \\
500 a menos de 1.000 & 318 & $12,83 \%$ & $225.501,59$ & $20,25 \%$ \\
Acima de 1.000 & 302 & $12,18 \%$ & $701.652,38$ & $62,99 \%$ \\
\hline Total & $\mathbf{2 . 4 7 8}$ & $\mathbf{1 0 0 \%}$ & $\mathbf{1 . 1 1 3 . 8 2 3 , 4 5}$ & $\mathbf{1 0 0 \%}$ \\
\hline
\end{tabular}

Fonte: INCRA/SNCR - 2014. Apud Nardoque (2016, p.274). 
As contradições do cerceamento das políticas públicas para a educação do campo em Três Lagoas (MS):

Escola Estadual Afonso Francisco Xavier Trannin e

Escola Municipal Profa. Elma Garcia Lata Batista

Em trabalho de campo, percebeu-se a frequente tentativa de dominação ideológica $^{2}$, principalmente nas escolas, por parte das grandes empresas, em aliança com o Estado. O Território Rural do Bolsão é marcado/assolado pelo domínio/posse e uso da terra e pelas articulações superestruturais (NARDOQUE, 2016) das duas grandes empresas do ramo de papel e celulose: Fíbria e Eldorado.

Dessa forma, Nardoque e Almeida (2015) alertam para a consequência dessa dominação do Território Rural do Bolsão pela expansão dos setores empresariais: a redução da população do campo, como demonstrado nas residenciais fechadas (Figura 4) nas fazendas que tiverem o uso da terra alterado de pecuária para monocultivos de eucaliptos.

Figura 4 - Três Lagoas (MS), Distrito de Garcias: casa fechada/abandonada.

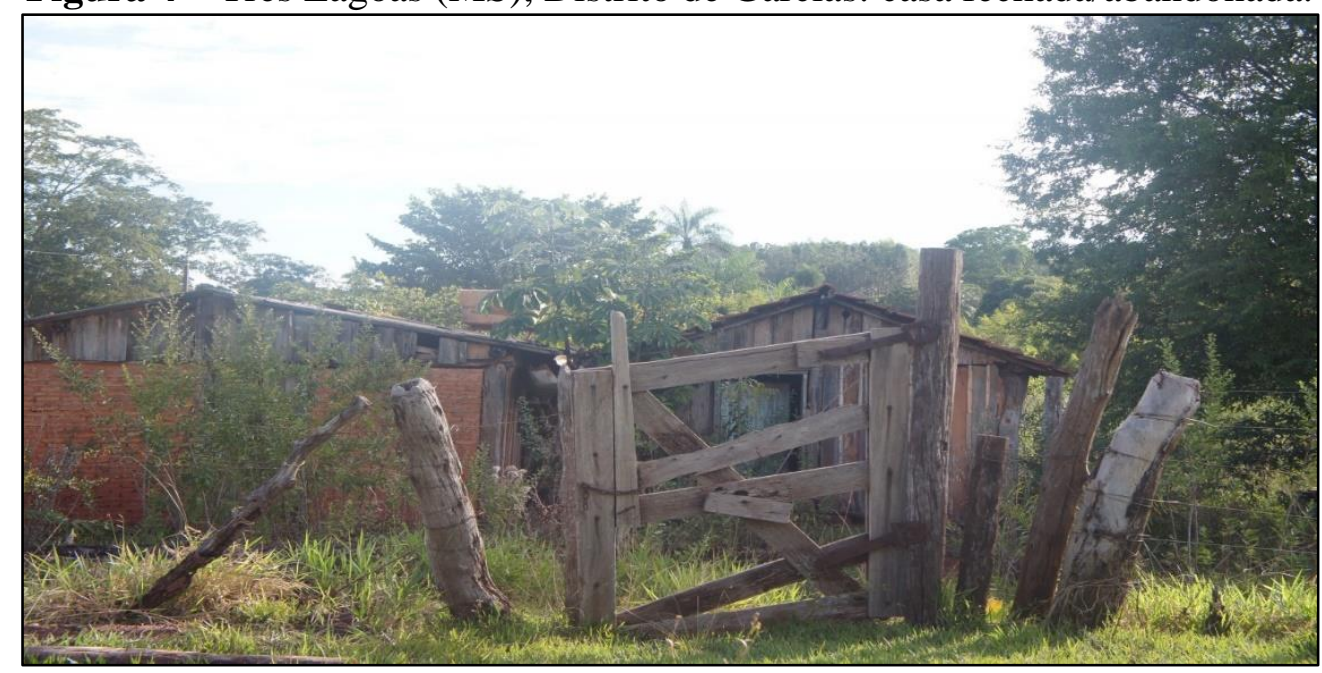

Fonte: Trabalho de campo.

Foto: MACEDO, F. R. 17, mai. 2016.

Nardoque e Almeida (2015) denunciam outros fatores, no Território Rural do Bolsão, que dificultam o direito de permanecer na terra, sobretudo para os assentados de Reforma Agrária: a falta de infraestruturas e de políticas públicas que concedam o mínimo para a sobrevivência no campo, como moradia, água e energia elétrica. Citando como exemplo o PA São Joaquim, situado no município de Selvíria, onde até pouco tempo, os assentados sequer tinham acesso à energia elétrica, casa de alvenaria e estradas adequadas.

[...] está ocorrendo um movimento contraditório, ou seja, enquanto temos indústrias que estão se estabelecendo no campo como é o caso das usinas de álcool e açúcar e das indústrias de celulose e papel, os 
As contradições do cerceamento das políticas públicas para a educação do campo em Três Lagoas (MS):

Escola Estadual Afonso Francisco Xavier Trannin e

Escola Municipal Profa. Elma Garcia Lata Batista
Francielle Rodrigues de Macedo Sanches Sedeval Nardoque

trabalhadores do campo (bóias frias e assalariados) estão fixando moradia nas cidades. (KUDLAVICZ, 2011, p. 28).

Por falta de políticas públicas mais efetivas, há diminuição da população do campo, bem como a oferta de empregos para assentados de Reforma Agrária:

A ausência de infraestrutura do assentamento [...] implica na saída dos adultos para trabalharem nos plantios de eucaliptos das empresas do setor de eucalipto/celulose, implicando em círculo vicioso da retirada dos trabalhadores da terra e na diminuição da produção. (NARDOQUE e ALMEIDA, 2015, p. 05 e 06).

Em um panorama geral, no Território do Bolsão, onde a dominação do capital mata a biodiversidade, mune-se da biotecnologia para fabricação de uma segunda natureza (KUDLAVICZ, 2011) e faz dos sujeitos do campo, por meio das suas práticas ideológicas, reserva de mão de obra (NARDOQUE e ALMEIDA, 2015). É o que a pesquisa de campo desnudou: uma diminuição de matrículas e falta de políticas para o campo nas escolas rurais, colaborando para a diminuição da população camponesa no campo e fechamento das poucas escolas rurais de Três Lagoas.

A gestação de todo esse processo, de inserção do atual estado de Estado de Mato Grosso do Sul, ocorreu entre a década de 1960 e 1970, como palco de ações governamentais para suprir a demanda por matéria prima, ficando sempre a sombras dos financiamentos estrangeiros e nacionais, se comparado com o desenvolvimento da região Sudeste e Sul. As obras para a região Centro-Oeste eram basicamente construções de sistemas de transportes para escoamento das matérias primas.

Destacamos de modo particular a década de 1970, após o golpe militar de 1964, quando a estratégia de integração passa a ser perseguida como objetivo principal do Estado brasileiro, para tanto foram elaboradas políticas públicas direcionadas para a ocupação econômica da região Amazônica e do Centro-Oeste, de modo específico com a elaboração e execução do II Plano Nacional de Desenvolvimento (II PND). (KUDLAVICZ, 2011, p. 42).

O poder executivo nacional na década de $1970 \mathrm{em}$ diante, passou a financiar as ações das empresas em território nacional brasileiro, a priori, construindo os fluxos. Assim, o vasto território foi marcado pelas práticas fraudulentas de auto apropriação da terra por latifundiários, acompanhadas da expansão da pecuária. Esta daria gradativamente lugar ao pinus. 
Como resultado dessa política de ocupação do cerrado na década de 1970, através de amplo financiamento público e de vantagens fiscais, temos o início da 'eucaliptização' da Microrregião de Três Lagoas culminando na retomada e aprofundamento no século XXI. Ação essa encaminhada sob o manto da 'vocação florestal'. (KUDLAVICZ, 2011, p. 49).

Silva (2014) relata a diminuição da população do campo e da residente nas sedes dos distritos (Arapuá e Garcias), por conta da mudança da função econômica sob a ótica do capital dito moderno no território.

Em relação aos impactos sociais, observamos que os arrendamentos e venda de fazendas de criação de gado para o plantio de eucalipto, acabaram provocando ondas de desemprego de famílias que estavam trabalhando e, inclusive, muitas, delas residentes nas fazendas. Os relatos de moradores de duas comunidades rurais de Três Lagoas, no caso Garcias e Arapuá, revelam que, por volta do ano de 1996, residiam 25 famílias na fazenda Nippak, 15 famílias na fazenda Vista Alegre e a fazenda Serrinha tinha, aproximadamente, 50 famílias. Estes números não fazem mais parte da realidade, pois essas fazendas foram arrendadas para o plantio de eucalipto e as famílias desempregadas. (SILVA, 2014, p. 132).

É nesse território marcado pela conflituosidade que a Educação do Campo se faz necessária como ferramenta contra hegemônica. Nesse sentido, Kudlavicz e Almeida (2008) acrescentam que por ser considerada desnecessária pelo governo, pensar em uma Educação do Campo, voltada aos camponeses, nunca foi prioridade. O discurso justificase amparado na falácia que o camponês desapareceria engolido pelas práticas do agronegócio, transformando os povos do campo em mão de obra barata, sucumbindo-os e submetendo-os a um modo de vida embasado na competitividade do mercado, alimentando, assim, os lucros dos detentores dos meios de produção e de terra.

\section{O lugar da educação do/no campo em Mato Grosso do Sul}

A ocupação, em 1984, da fazenda Santa Idalina, em Ivinhema/MS, tornou-se o marco histórico de resistência camponesa e o início da implantação dos assentamentos da Reforma Agrária no estado de Mato Grosso do Sul.

Por conseguinte, algumas cidades outrora totalmente abandonadas, com a implantação dos assentamentos experimentam o aquecimento/fortalecimento da economia local, do mercado interno, da movimentação de crédito, ou seja, o 'ressurgimento' de algumas 
As contradições do cerceamento das políticas públicas para a educação do campo em Três Lagoas (MS):

Escola Estadual Afonso Francisco Xavier Trannin e

Escola Municipal Profa. Elma Garcia Lata Batista
Francielle Rodrigues de Macedo Sanches Sedeval Nardoque

cidades que estavam num processo de decadência econômica e redução populacional. (KUDLAVICZ e ALMEIDA, 2008, p. 22).

Naquele contexto, Kudlavicz e Almeida (2008) apontam as dificuldades dos profissionais e materiais didáticos reaproveitados implantados nas escolas do campo, sobretudo nas escolas rurais existentes:

[...] era comum os materiais didáticos usados na área rural serem os mesmos oferecidos nas escolas da cidade. Por outro lado, muito material escolar que não servia mais para as escolas urbanas, ou porque estava defasado ou então em péssimas condições, era distribuído para as escolas rurais. Aos professores que moravam na cidade, mas lecionavam nas escolas rurais, o Estado não oferecia condições materiais de estadia e de incentivo para o exercício de sua atividade de professor. Com o agravante da maioria dos professores que se deslocavam da cidade para lecionar no campo desconhecerem absolutamente a realidade cotidiana rural. Assim, mal assistidos e deslocados tornavam-se meros depositários de um conhecimento alheio ao cotidiano dos seus alunos. (KUDLAVICZ e ALMEIDA, 2008, p. 23).

Segundo Lemes e Nardoque (2016), a partir da preocupação em se ter uma educação (por direito) para o campo, com profissionais do campo, é que a CPT, na década de 1990, na região de Dourados, tornou-se responsável pelo material didático e elaboração de um Projeto Político-Pedagógico para o campo. Analisando o contexto na mesma década, Kudlavicz e Almeida (2008) ressaltam que, em Mato Grosso do Sul, as ações orientadas pela CPT, e, posteriormente, incorporadas às Diretrizes Operacionais para Educação Básica (2002), estavam sendo realizadas.

Em vista desta realidade a CPT/MS toma a iniciativa, juntamente com as lideranças dos acampados, de formar um grupo voluntário a fim de realizar um trabalho educativo com as crianças acampadas no sentido de alfabetizá-las e, ao mesmo tempo, mantê-las com algum tipo de atividade/ocupação própria [...]. (KUDLAVICZ e ALMEIDA, 2008, p. 27).

Em meados do final da década de 1980, após uma ação do governo em reunir todas as famílias acampadas (totalizando 840 famílias) no município de Dois Irmãos do Buriti, a CPT deu o primeiro passo para a formação de base, oferecendo formação e direcionamento a voluntários dispostos a lecionar segundo as práticas camponesas e, posteriormente, reconhecimento da importância da formação continuada dos professores, transformando-a em lei. O primeiro e o segundo Encontro Estadual de Professores de Acampamentos e Assentamentos de Mato Grosso do Sul buscavam organizar o trabalho 
As contradições do cerceamento das políticas públicas para a educação do campo em Três Lagoas (MS):

Escola Estadual Afonso Francisco Xavier Trannin e

Escola Municipal Profa. Elma Garcia Lata Batista
Francielle Rodrigues de Macedo Sanches Sedeval Nardoque

feito com os professores e, nesse sentido, o "Magistério de Férias" foi criado para oferecer continuidade nos estudos a professores com $2^{\circ}$ grau incompleto (atual Ensino Médio). (KUDLAVICZ e ALMEIDA, 2008).

Segundo Kudlavicz e Almeida (2008), o reconhecimento do Ministério de Educação, no que diz respeito à validação do "Magistério de Férias", a CPT buscou parcerias com outras entidades vinculadas à Igreja católica, com a prefeitura de Campo Grande e com a UFMS. Foi então que no Campus de Três Lagoas, em 1995, houve o debate sobre o tema para o município por meio do seminário que buscava discutir a situação da educação nos assentamentos e carvoarias em Mato Grosso do Sul. O resultado das discussões foi a elaboração de proposta pedagógica para que se atendesse o modo de vida camponês.

Depois da visibilidade da Educação do Campo em Mato Grosso do Sul, houve algumas vitórias, a se destacar: a criação das Escolas Família Agrícola (EFAs), onde a Pedagogia da Alternância regia o Plano Político-Pedagógico; A criação do Comitê da Educação Básica do Campo em Mato Grosso do Sul (SED, ${ }^{\circ}$ 1507/01); e projeto "Saberes da Terra" (KUDLAVICZ e ALMEIDA, 2008).

Ao considerar a importância das lutas pela terra e direitos dos camponeses, destaca-se a importância de grupos de estudos e de produção científica em geral, denunciando o campo conflituoso. Nesse sentido, ressalta-se a importância da implantação do projeto Núcleo de Extensão em Desenvolvimento Territorial do Bolsão/MS (NEDET/MS), criado a partir de edital proposto pelo extinto Ministério de Desenvolvimento Agrário (MDA) e o Conselho Nacional de Pesquisa (CNPq).

[...] o Núcleo de Extensão em Desenvolvimento Territorial do Bolsão (MS) com a finalidade de implementar propostas de desenvolvimento territorial endógeno que contemplem antigas bandeiras de lutas dos movimentos e organizações sociais tais como: aplicação das políticas agrícolas para efetivação da Reforma Agrária, em particular no tocante à infraestrutura dos assentamentos; implementação das políticas públicas de crédito e comercialização das políticas de crédito e comercialização para o fortalecimento da agricultura familiar camponesa; estímulo a participação das mulheres na geração de renda no campo; expansão e consolidação da Educação do/no Campo; construção da transição agroecológica. (NARDOQUE e ALMEIDA, 2015, p.02).

Dessa forma, destaca-se a importância da tríade extensão-ensino-pesquisa que 
As contradições do cerceamento das políticas públicas para a educação do campo em Três Lagoas (MS):

Escola Estadual Afonso Francisco Xavier Trannin e

Escola Municipal Profa. Elma Garcia Lata Batista
Francielle Rodrigues de Macedo Sanches Sedeval Nardoque

percorrem a ciência geográfica na Universidade Federal de Mato Grosso do Sul, Campus de Três Lagoas (UFMS/CPTL), que faz despertar para a realidade de lutas de classes, principalmente no que tange à questão agrária no Bolsão Sul-mato-grossense.

No município de Três Lagoas, analisando num recorte temporal de 2010 a $2016^{3}$ (tabela 2), contava-se com apenas uma escola estadual rural: Escola Estadual Afonso Francisco Xavier Trannin (localizada no Distrito Arapuá), onde, em 2010, o número de matrículas geral era de 536, sendo 391 no ensino fundamental, 116 no ensino médio e 29 na Educação de Jovens e Adultos (EJA). Ao comparar esses dados com os de 2016, observa-se queda no número de matrículas: 443, dessas 360 em ensino fundamental, 83 em ensino médio e nenhum na EJA.

Tabela 2 - Escola Estadual Afonso Francisco Xavier Trannin: censo escolar.

\begin{tabular}{c|ccc|c|c|c|c|c}
\hline & 2010 & 2011 & 2012 & 2013 & 2014 & 2015 & 2016 \\
\hline $\begin{array}{c}\text { Ensino } \\
\text { Fundamental }\end{array}$ & 391 & 390 & 408 & 418 & 383 & 348 & 360 \\
$\begin{array}{c}\text { Ensino } \\
\text { Médio }\end{array}$ & 116 & 103 & 94 & 96 & 88 & 81 & 83 \\
EJA & 29 & 25 & 20 & 15 & 14 & 0 & 0 \\
\hline $\begin{array}{c}\text { Total geral } \\
\text { por anos }\end{array}$ & 536 & 518 & 522 & 529 & 485 & 429 & 443 \\
\hline
\end{tabular}

Fonte: Secretaria de Educação de Mato Grosso do Sul. Org. MACEDO, F. R.

No que tange a esfera do ensino municipal em Três Lagoas, munindo-se da análise dos dados do mesmo período mencionado anteriormente, em 2010 contava com duas escolas municipais para o campo, sendo elas: Escola Municipal Profa. Elma Garcia Lata Batista (localizada no Distrito Garcias) e Escola Municipal Antônio Camargo Garcia (Localizada na Rodovia MS 377 - Km 80). Esse quadro mudou no ano de 2015, quando somente era considerada uma escola do campo, esta segunda, permanecendo nos documentos até o ano de 2016.

Relacionado ao número de matriculados, a Escola Municipal Profa. Elma Garcia Lata Batista, no ano de 2010 (tabela 3), contava com 115 alunos matriculados, oferecendo somente ensino fundamental, quadro que mudou em 2012, quando, de 57 alunos matriculados num número geral, 48 estavam na modalidade de ensino fundamental e 9 na modalidade de educação infantil. A oferta de educação infantil permaneceu até 2014. Naquele ano, a Escola Municipal Profa. Elma Garcia Lata Batista, contava com 60 alunos, 
As contradições do cerceamento das políticas públicas para a educação do campo em Três Lagoas (MS):

Escola Estadual Afonso Francisco Xavier Trannin e

Escola Municipal Profa. Elma Garcia Lata Batista
Francielle Rodrigues de Macedo Sanches Sedeval Nardoque

desses, 25 na modalidade de educação infantil e 35 no ensino fundamental.

Tabela 3 - Escola Municipal Profa. Elma Garcia Lata Batista: censo escolar.

\begin{tabular}{cccccc}
\hline & 2010 & 2011 & 2012 & 2013 & 2014 \\
\hline $\begin{array}{c}\text { Ensino } \\
\text { Fundamental } \\
\text { Educação } \\
\text { Infantil }\end{array}$ & 115 & 101 & 48 & 45 & 35 \\
\hline $\begin{array}{c}\text { Total geral } \\
\text { por anos }\end{array}$ & 115 & 101 & 57 & 69 & 60 \\
\hline
\end{tabular}

Fonte: Secretaria de Educação de Mato Grosso do Sul.

Org. MACEDO, F. R.

Apesar de não ser objeto dessa pesquisa, ao analisar a disponibilidade de matrículas que atendem aos sujeitos do campo, na Escola Municipal Antônio Camargo Garcia, se faz necessária, pois, até o ano de 2016, constituiu a única escola municipal rural em Três Lagoas. Assim, analisando o número de matriculados no ano de 2010 (tabela 4), a escola municipal contava 281 matriculados no ensino fundamental e, em 2016, 219 matriculados.

Tabela 4 - Censo Escolar da Escola Municipal Antônio Camargo Garcia.

\begin{tabular}{lccccccc}
\hline & 2010 & 2011 & 2012 & 2013 & 2014 & 2015 & 2016 \\
\hline $\begin{array}{c}\text { Ensino } \\
\text { Fundamental }\end{array}$ & 281 & 223 & 158 & 160 & 157 & 178 & 219 \\
\hline $\begin{array}{l}\text { Total geral } \\
\text { por anos }\end{array}$ & 281 & 223 & 158 & 160 & 157 & 178 & 219 \\
\hline
\end{tabular}

Fonte: Secretaria de Educação de Mato Grosso do Sul.

Org. MACEDO, F. R.

Dessa forma, as escolas rurais públicas, estadual e municipal, no município de Três Lagoas, atenderam, de 2010 a 2016, 5.240 alunos, desses, as escolas aqui estudadas atenderam 3.864 alunos.

Ao analisar as tabelas nos anos de 2010 a 2016, observa-se que houve queda no número de matrículas das escolas do campo mencionadas anteriormente. Subtraindo os números, houve queda de 55 matrículas na Escola Municipal Profa. Elma Garcia Lata Batista (levando em consideração o tempo vigente como escola do campo, até 2014); 62 matrículas na Escola Municipal Antônio Camargo Garcia; 93 matrículas na Escola Estadual Afonso Francisco Xavier Trannin.

Os números mostram as consequências das práticas das empresas no território, de 
As contradições do cerceamento das políticas públicas para a educação do campo em Três Lagoas (MS):

Escola Estadual Afonso Francisco Xavier Trannin e

Escola Municipal Profa. Elma Garcia Lata Batista
Francielle Rodrigues de Macedo Sanches Sedeval Nardoque

forma tamanha que transformou a Escola Municipal Profa. Elma Garcia Lata Batista em uma extensão da escola da cidade (Extensão da Escola Municipal Gentil Rodrigues Montalvão) em 2015.

Está diminuindo os moradores do campo e, consequentemente, dos alunos nas escolas, além do que, a não efetivação de políticas públicas para o campo gera a exclusão escolar do camponês, evidenciado pela diminuição de matrículas do ensino fundamental para o médio e extinção da EJA, na Escola Estadual Afonso Francisco Xavier Trannin.

A territorialização do capital é contraditória, ao mesmo tempo que produz riqueza para poucos latifundiários, dissemina exclusão e pobreza para os muitos camponeses. Dessa forma, a (re)criação camponesa se faz presente em Três Lagoas. Apesar da diminuição de matrículas, a Escola Estadual Afonso Francisco Xavier Trannin (Distrito Arapuá), tem discentes provenientes de assentamento de Reforma Agrária (PA 20 de Março) que vêm a escola de forma emancipatória, cuja busca resiste à territorialização do capital, mesmo que parcial.

Percebemos dessa forma que além das transformações socioterritoriais impostas pelo capital monocultor há também a recriação do campesinato, impondo um novo modelo de resistência que impeça o seu desaparecimento, partindo das práticas camponesas adquiridas através das raízes familiares, no trabalho, nas atividades diárias não esquecidas que agora afloram no interior do Distrito, ou seja, difunde em outro espaço seu pertencimento.

Por isso, entendemos que a realização da prática de ensino junto aos alunos do campo é imprescindível o reconhecimento das práticas camponesas relatadas por eles, pois somente através das relações homem/campo é que se pode traçar um ensino voltado ao cotidiano desses alunos, sem deixar que se perca o sentido social e espacial do camponês. (MEDEIROS, 2014, p. 15).

A realidade deixa claro que o campo não está vazio e transparece a resistência/resiliência dos alunos camponeses (mesmo sendo em escolas no campo) contra a territorialização total do capital via monocultivo de eucalipto.

Os números denunciam processos em cursos, evidenciando a grande probabilidade da extinção das escolas rurais no município de Três Lagoas, mas também dando visibilidade à resistência dos camponeses em permanecer no campo que não está vazio de gente.

Dessa forma, os estudos apontados a seguir justificarão a diminuição dos camponeses nas escolas estudadas pela não efetivação das leis para Educação do Campo 
As contradições do cerceamento das políticas públicas para a educação do campo em Três Lagoas (MS):

Escola Estadual Afonso Francisco Xavier Trannin e

Escola Municipal Profa. Elma Garcia Lata Batista
Francielle Rodrigues de Macedo Sanches Sedeval Nardoque

e evidenciará que apesar de não encontrar na realidade das escolas os pilares sustentantes das leis, embasados nos princípios da Educação do Campo, as escolas mostram-se como forças contra hegemônicas que impedem a territorialização total do capital e transparecem um campo vivo, não harmônico e não acomodado.

A Escola Estadual Afonso Francisco Xavier Trannin não tem infraestrutura adequada para educação de qualidade. A equipe de gestão escolar e a comunidade não participam da tomada de decisões acerca das políticas públicas estaduais, pois são direcionadas pela Secretaria de Estado da Educação. Situação diferente foi encontrada na Escola Municipal Elma Garcia Lata Batista, segundo o funcionário entrevistado, havia boa articulação entre escola-comunidade-governo municipal. Isso é evidente se comparadas às infraestruturas das duas.

No distrito Garcias havia parcerias da escola com a Fíbria (atual Suzano) e a Eldorado Brasil (do setor de celulose) com a comunidade, mas foi negado durante as falas nas entrevistas qualquer material didático ou influência (direta) na escola por essas empresas.

Segundo Kudlavicz (2011) e Lemes (2014), o espaço rural de Três Lagoas sofre com as práticas das empresas do setor celulose que estendem suas ações à educação por meio de acordos com o governo municipal, estadual e escolas técnicas. Essa articulação ocorre pelo Sistema "S". Este último é composto por:

Serviço Nacional de Aprendizagem Industrial (Senai); Serviço Social do Comércio(Sesc); Serviço Social da Indústria (Sesi); e Serviço Nacional de Aprendizagem do Comércio (Senac).Existem ainda os seguintes: Serviço Nacional de Aprendizagem Rural (Senar); Serviço Nacional de Aprendizagem do Cooperativismo (Sescoop); Serviço Social de Transporte (Sest), Serviço Nacional de Aprendizagem do Transporte (Senat), Serviço Brasileiro de Apoio às Micro e Pequenas Empresas (Sebrae), Diretoria de Portos e Costas do Ministério da Marinha (DPC) e Instituto Nacional de Colonização e Reforma Agrária (INCRA). (LEMES, 2014, p. 113-114).

As vagas são destinadas a aqueles de baixa renda que estejam matriculados na Educação Básica. Lemes (2014) ressalta que a oferta de cursos técnicos é para atender a lógica e demanda de mão de obra das empresas (Fíbria e Eldorado Brasil). "Nesse acordo a educação é revelada como ponto essencial das políticas governamentais e do discurso empresarial” (LEMES, 2014, p. 114).

A articulação e aliança entre poderes executivos públicos e empresas privadas, 
As contradições do cerceamento das políticas públicas para a educação do campo em Três Lagoas (MS):

Escola Estadual Afonso Francisco Xavier Trannin e

Escola Municipal Profa. Elma Garcia Lata Batista
Francielle Rodrigues de Macedo Sanches Sedeval Nardoque

fazem com que a educação oferte o que a lógica do mercado necessita. Para Lemes (2014), os cursos superiores e pós-graduação fazem parte da engrenagem do sistema no atendimento às empresas, fica assim,

[...] evidente a demanda do agronegócio da celulose na realidade educativa organizacional de Três Lagoas e de sua microrregião. Haja vista o modo que se apropria da educação e limita suas potencialidades para atender seus interesses. (LEMES, 2014, p. 117).

Para Lemes (2014), as empresas do setor de celulose utilizam-se das "sementes do diálogo" para antecipação de conflitos e revela a confusão dos projetos das mesmas para educação.

O primeiro equívoco sobre o projeto pedagógico está direcionado à confusão de linguagem, que significa o termo empregado refletir a confusão do real significado ao qual está inserido o projeto [...] A segunda confusão aparece sobre a ação pedagógica, que implica na forma como é predeterminado o projeto, a ação [...] A terceira confusão refere-se às motivações contraditórias, pois as intencionalidades de aplicação do projeto se mostra um tanto ambíguas, ao mesmo tempo que revela certa unanimidade nas correntes conflituais que perpassa $o$ campo pedagógico. (LEMES, 2014, p. 119-120).

Kudlavicz (2011) alertou para a modificação da vida dos camponeses com a chegada do plantio de eucalipto nos distritos Garcias e Arapuá e evidenciou processo em curso do fechamento da Escola Municipal Profa. Elma Lata Garcia (em 2010):

Na concepção dos comerciantes locais o eucalipto trouxe o fracasso do Distrito, explicam que o comércio não tem o movimento que tinha nos finais de semana. Alegam que até mesmo a escola corre o risco de ser fechada, pois em 2009 estavam matriculados 198 alunos e, em 2010, este número reduziu para 150 alunos. Logo, há probabilidade de no ano seguinte (2011) ocorrer à desativação da $1^{a}$ série do ensino fundamental por falta de alunos.

Este problema da falta de alunos não é exclusivo dessa comunidade, a situação se repete em Arapuá, por exemplo. Em visita a escola desse Distrito, em junho de 2010, os professores e diretores da escola Estadual de Arapuá relataram fatos muito semelhantes como consequiência da venda e arrendamento das fazendas para o plantio de eucalipto. (KUDLAVICZ, 2011, p. 145).

Para Medeiros (2014), as ações de arrendamento geram insegurança dos jovens camponeses acerca da permanência na terra no Distrito Arapuá, fazendo com que haja elevado número de migração do campo para cidade. Mesmo assim,

[...] no distrito a resistência do campesinato, mesmo com todas as dificuldades encontradas para recriarem seu modo de vida, e na terra 
As contradições do cerceamento das políticas públicas para a educação do campo em Três Lagoas (MS):

Escola Estadual Afonso Francisco Xavier Trannin e

Escola Municipal Profa. Elma Garcia Lata Batista
Francielle Rodrigues de Macedo Sanches Sedeval Nardoque

assegurar na terra o autoconsumo e renda para o grupo familiar, buscando meios para permanecer no campo [...] (MEDEIROS, 2014, p. $13)$.

No que se refere ao material didático e estruturas curriculares, a escola municipal Profa. Elma Garcia Lata Batista trabalhava com o sistema apostilado do Positivo, preparado para ensino nas escolas da cidade. Seguiam também o calendário e estrutura curriculares urbanos, dessa forma o artigo $5^{\circ}$ da resolução $n^{\circ} 1$ de abril de 2002, que garante o projeto pedagógico que contemple a diversidade cultural próprias do campo, não foi cumprido.

A escola é conduzida por seu Projeto Político Pedagógico (PPP) e este deve ser fiel às diretrizes garantidas por direito para a Educação do Campo. Pontin e Nardoque (2016) denunciam as práticas advindas de governos neoliberais no Bolsão/MS, onde o Projeto Político Pedagógico voltado para o campo vem sendo sucumbido. A implantação do apostilado Positivo causa grande repercussão na rede de ensino para o campo por não atender suas especificidades. Sobre as influências da Fíbria e da Eldorado Brasil nas escolas: "Sabe-se que a atuação dessas empresas com a educação é vista como de 'responsabilidade social', porém exercendo papel de cunho ideológico, uma vez que não solucionam os problemas levantados pela comunidade [...]" (PONTIN e NARDOQUE, 2016, p. 161-162).

Freitas (2012), ao analisar escola rural em Bataguassu (MS), alerta para o Projeto Político Pedagógico e a falta de conhecimento dos professores quanto aos princípios e projetos do Estado voltados para a Educação do Campo. Denuncia a inércia do governo de Mato Grosso do Sul em capacitar os professores para um projeto de Educação do Campo, mas relata a visão dos alunos sobre a escola, onde a maioria das respostas foram direcionadas para a excelência do corpo docente. A autora deixa transparecer na fala dos alunos camponeses o quão importante e vivo é o vínculo dos mesmos com a terra. Os professores evidenciam a importância das políticas públicas para a Educação do Campo e melhorias que essas trazem.

Segundo relato dos educadores, já foram sentidos avanços na escola desde sua criação, pois, quando a escola iniciou, existiam apenas salas multisseriadas que não atendiam a todos os níveis de ensino e alguns educadores que estavam em sala de aula não possuíam qualificação, uma vez que não havia professores suficientes para compor o quadro de funcionários. Além disso, os educandos não tinham transporte escolar 
As contradições do cerceamento das políticas públicas para a educação do campo em Três Lagoas (MS):

Escola Estadual Afonso Francisco Xavier Trannin e

Escola Municipal Profa. Elma Garcia Lata Batista
Francielle Rodrigues de Macedo Sanches Sedeval Nardoque

para chegar à escola e as estradas eram muito ruins, o que dificultava o acesso dos mesmos, ainda que a pé. (FREITAS, 2012, p. 133).

As escolas de Três Lagoas são organizadas em sistema seriado - somente em casos de baixo número de alunos, como na E.E. Afonso Francisco Xavier Trannin, obrigase a junção de salas, tornando-as multisseriadas. Outra característica de ambas escolas é a não adoção da Pedagogia da Alternância.

Para Camacho (2013), as práticas de uma educação rural mal implementada é a causadora da exclusão escolar, pois, desconsidera totalmente os princípios camponeses embasados no "trabalho essencialmente familiar". Nesse sentido, o autor ressalta que o trabalho é mais do que labutar, representa neste caso o sentimento de pertença a um lugar que é próprio do camponês (CAMACHO, 2013).

Assim, entende-se a importância de um Projeto Político Pedagógico que condiz com as práticas camponesas, haja vista que um currículo elaborado bem como seu material apostilado urbano, causam a perda da identidade do camponês.

O trabalho no campo é necessário, desde a infância até a juventude, a ajudar com a lida da terra. Isso é um princípio da agricultura familiar, pois a família cuida do que a natureza lhe dá, garantindo assim a diversidade e soberania alimentar. Camacho (2013) alerta para a não confusão quanto ao entendimento do trabalho infantil camponês e trabalho infantil escravo.

Enquanto a primeira é uma relação social não-capitalista, a segunda é uma relação social capitalista baseada na exploração do trabalho. No trabalho camponês, o seu produto não é alheio/estranho àquele que o produziu, se misturando, muitas vezes, às atividades de lazer dos estudantes camponeses. (CAMACHO, 2013, p. 337).

A escola estadual do distrito de Arapuá tem uma grade curricular adaptada ao ensino do campo. O material didático do $1^{\circ}$ ao $5^{\circ}$ ano - chamado Projeto Girassol (Figura 5) - é específico para o campo. No entanto, ressalta-se que o material fica à disposição do professorado para preparação e aplicação das atividades voltadas para o campo, além do que, não abrange toda a comunidade dessa escola, haja vista que não atende aos alunos do ciclo fundamental II nem aos do ensino médio. 
As contradições do cerceamento das políticas públicas para a educação do campo em Três Lagoas (MS):

Escola Estadual Afonso Francisco Xavier Trannin e

Escola Municipal Profa. Elma Garcia Lata Batista
Francielle Rodrigues de Macedo Sanches Sedeval Nardoque

Figura 5 - Material Projeto Girassol

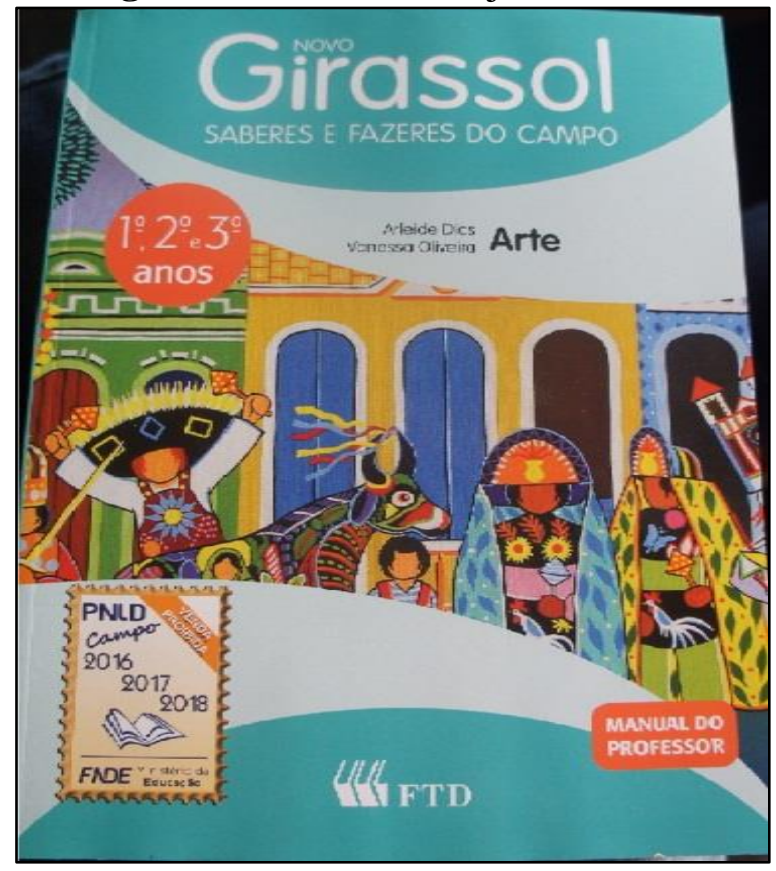

Fonte: Trabalho de campo.

Foto: MACEDO, F. R. 17, mai. 2016.

As escolas não trabalham com a Pedagogia da Alternância. O sistema seriado adotado pelas escolas do campo é o mesmo das escolas da cidade, pois têm em seus currículos as perspectivas políticas de um mundo urbano, sem levar em consideração a valorização da vivência dos alunos do campo, a troca de experiências entre eles, as características próprias aos seus lugares de vivência.

As escolas rurais também sofrem por outra causa: o material didático de baixa qualidade utilizado, pois enaltecem as cidades e trazem o campo como lugar atrasado, sobretudo aquele de vivência do campesinato. "A educação é pensada a partir do mundo urbano e retrata o campo a partir do olhar do capital e seus sujeitos são vistos de forma estereotipada, inferiorizada" (NARDOQUE, 2015, p. 114), assim,

[...] as políticas educacionais, os currículos são pensados para a cidade, para a produção industrial urbana, e apenas lembram do campo quando lembram de situações 'anormais', das minorias, e recomendam adaptar as propostas, a escola, os currículos, os calendários a essas 'anormalidades'. [...] O suposto é que as propostas, os conteúdos são iguais para todos e devem ter a mesma finalidade: habilitar todas as crianças e jovens do campo ou da cidade para as experiências modernas da produção e do mercado. (ARROYO e FERNANDES, 1999, p. 24).

Os professores, nas escolas onde o trabalho de campo foi realizado, afirmam sobre 
As contradições do cerceamento das políticas públicas para a educação do campo em Três Lagoas (MS):

Escola Estadual Afonso Francisco Xavier Trannin e

Escola Municipal Profa. Elma Garcia Lata Batista
Francielle Rodrigues de Macedo Sanches Sedeval Nardoque

a precariedade das escolas públicas rurais por falta de infraestrutura e inadequação do material didático ${ }^{4}$. Há ausência do poder estatal para prover o mínimo de estruturas físicas necessárias para uma boa convivência com o espaço e, consequentemente, uma boa aprendizagem, resultando assim na não efetivação do Art. $7^{\circ}$, Art. $8^{\circ}$, inciso IV e Art. 10 (da resolução $\mathrm{n}^{\circ} 1$, de abril de 2002), que dispõe, sequencialmente, sobre a flexibilização do calendário escolar, de forma que respeite, principalmente, o tempo do camponês e o estreitamento das relações que permeiam a Educação do Campo: órgãos governamentais; movimentos sociais e demais setores da sociedade. As práticas desrespeitam também o Art. $5^{\circ}$ e Art. $10, \S 1^{\circ}$ da resolução $n^{\circ} 2$ de abril de 2008 , cujos dispõe sobre diálogo com a comunidade no que diz respeito à organização da educação.

Partindo da análise de Camacho (2013), se vê que a Educação do Campo que considera o meio de trabalho-lazer-ensino, cujo o lecionar emancipatório é subversivo ao modo de ensinar hegemônico, por, principalmente, considerar o tempo comunidade. Entende-se assim a importância da Pedagogia da Alternância.

Segundo Camacho (2013), a educação do camponês deve ser analisada mais profundamente, de forma que se contemple o tempo seguido por esses sujeitos de direito, ou seja, o tempo da natureza e não das empresas.

Logo, a relação da educação com o modo de vida do estudantecamponês -contemplando o tripé terra/território-família-trabalho respeitando suas espacialidades-temporalidades e sua identidade territorial e de classe, é uma das motivações centrais que sustentam a necessidade ontológica e epistemológica da elaboração de um Paradigma da Educação do Campo. (CAMACHO, 2013, p. 340).

Outro entrave percebido nas duas escolas foi a formação dos professores voltada para a Educação do Campo. Somente alguns poucos professores da Escola Estadual Afonso Francisco Xavier Trannin participavam do Curso de Especialização em Educação do Campo oferecido pela Universidade Federal de Mato Grosso do Sul, campus de Três Lagoas.

Desta forma, estas características das escolas novamente não estão em consonância com os dispositivos legais - uma vez que é garantida a formação continuada do corpo docente para a Educação do Campo, disposto nos artigos 12, 13, 14 e 15, inciso III, da resolução n ${ }^{\circ} 1$ de abril de 2002 -, as práticas não garantem assim, uma gestão de formação para o campo, pois o alunado é protagonista da própria história, dessa forma, a 
As contradições do cerceamento das políticas públicas para a educação do campo em Três Lagoas (MS):

Escola Estadual Afonso Francisco Xavier Trannin e

Escola Municipal Profa. Elma Garcia Lata Batista
Francielle Rodrigues de Macedo Sanches Sedeval Nardoque

diversidade, a democracia e o respeito ao modo de vida no campo não são semeados (Art.

13, I e II). A não continuação na formação do professorado acarreta no não cumprimento do artigo 14 e artigo 15, inciso III, ambos dispõem sobre a valorização da carreira do professor e remuneração digna. As práticas também desrespeitam o Art. $7^{\circ}, \S^{\circ}$ e Art. 10 , $\S 2^{\circ}$ (Resolução $n^{\circ} 2$ de abril de 2008), que dispõe sobre a formação continuada do professor segundo as especificidades do campo.

É nesse sentido que Lemes e Nardoque (2016) ressaltam a importância das conquistas na formação do professorado para a Educação do Campo e reafirmam que esses profissionais devem ter compromisso social ao lecionar, uma vez que contribuirão como formadores de opinião.

Para atender, minimamente, a legislação vigente para as escolas e a educação oferecida aos sujeitos do campo, houve a introdução de Eixo Temático Terra-VidaTrabalho (TVT), em Mato Grosso do Sul.

Portanto, é imprescindível os conteúdos escolares propostos para a escola do campo serem direcionados para a promoção social, para a melhoria do ambiente rural e, principalmente, com o objetivo de fazer com que a população do campo tenha possibilidades de permanência na terra. Nessa perspectiva, para que as comunidades camponesas de Mato Grosso do Sul, atendidas pela escola do campo, fossem contempladas no currículo e tivessem relação com a realidade do campo, foi promulgada a Resolução/SED 2.501/2011, deliberando, em seu Art. $4^{\circ}$, que as escolas do campo teriam em suas propostas pedagógicas o Eixo Temático Terra-Vida-Trabalho, justamente para que as atividades escolares contribuíssem na formação dos estudantes, atendendo a realidade da comunidade. (LEMES E NARDOQUE, 2016, p. 144).

Lemes e Nardoque (2016), ao analisarem a efetivação do eixo temático TerraVida-Trabalho na Escola Estadual Afonso Francisco Xavier Trannin, afirmam que mesmo sendo garantido em lei, esse conteúdo voltado para o campo, tem defeitos na prática, são eles: a) conteúdos repetitivos; b) a falta de material adequado para planejamento das aulas; c) a quase inexistência de aulas práticas, sendo essas resumidas aos manejos da horta; d) o distanciamento da comunidade.

O Eixo Temático Terra, Vida e Trabalho, do $1^{\circ}$ ao $5^{\circ}$ ano, apresenta conteúdos iguais que o professor deve utilizar a metodologia de acordo com o ano letivo do educando, mas, mesmo assim, se torna repetitivo e os alunos reclamam dizendo: 'De novo isso? Nós já vimos isso'. Até 2015 eram ministradas três aulas semanais da disciplina de TVT e, a partir de 2016, esse número foi reduzido para duas aulas semanais. Quanto às aulas práticas, o professor não tem muita opção e acaba se 
limitando no plantio da horta e jardim. (LEMES e NARDOQUE, 2016, p. 146).

Lemes e Nardoque (2016) ressaltam ainda a importância dos professores não permanecerem ancorados somente aos eixos norteadores.

A escola do campo perpassa por limites históricos e sociais, e no que se refere à relação escola e comunidade, é preciso repensar sobre o poder destas relações no processo ensino/aprendizagem, na centralidade dos valores e saberes do homem e da mulher do campo. Assim, é na construção ou definição das propostas são selecionados conteúdos que ajudarão (ou não) os sujeitos a entenderem melhor a sua história e a compreenderem o mundo que os cercam. (LEMES e NARDOQUE, 2016, p. 148).

Nesse sentido, Floriano (2015) aponta para elaboração dos Parâmetros Curriculares Nacionais (PCNs) de cunho neoliberal, isso porque a educação é imposta pelos países hegemônicos aos periféricos, fragmentando o ensino, deixando-o vazio de conteúdos relacionados aos locais vividos pelos alunos, havendo assim, um distanciamento da ideia de lugar, logo contribuindo para uma deformação educacional acrítica. "A difusão do neoliberalismo exerceu forte pressão sobre os Estados no sentido de reverem suas práticas como reguladores ou interventores na economia e mantenedores de bens e serviços sociais" (FLORIANO, 2015, p. 98).

Segundo Floriano (2015), as práticas neoliberais, implantadas ao ensino, buscaram o seu desmanche nos últimos anos. Intensificadas na ditadura civil-militar, por meio da aprovação da Lei n ${ }^{0} 5.692 / 71$, que sucateou a educação, visando reserva de mão de obra qualificada assegurando o acesso à "educação para todos", não importando a qualidade da formação crítica, pelo contrário, por meio das

[...] mudanças no currículo, e na grade curricular com a criação das disciplinas de Estudos Sociais e de Educação Moral e Cívica, destinadas a substituir gradativamente a História e Geografia da grade curricular [...] A intensão da reforma, conduzida de maneira autoritária, era tornar inexpressivas as disciplinas de História e Geografia no interior do currículo. (FLORIANO, 2015, p. 99).

A autora afirma que no século XXI as práticas neoliberais impregnam a educação e torna o ensino fragmentado, pois ao professor cabe somente executar sob pressão o Plano Político Pedagógico (PPP), embasados nos PCNs e Referenciais Curriculares, transformando, assim, a educação em ensino bancário.

As abordagens da questão agrária articuladas com a luta de classes ficam sob a 
As contradições do cerceamento das políticas públicas para a educação do campo em Três Lagoas (MS):

Escola Estadual Afonso Francisco Xavier Trannin e

Escola Municipal Profa. Elma Garcia Lata Batista
Francielle Rodrigues de Macedo Sanches Sedeval Nardoque

vontade e a capacidade teórica do professor em problematizar, que se somente amparar suas aulas aos conteúdos a serem passados e as competências/habilidades a serem atingidas (lembrando que o Referencial Curricular é o documento basilar para a peneira dos conteúdos a serem abordados nos livros didáticos da rede pública de ensino), tornará desconexo da realidade do campo, haja vista que a todo o momento, sob um olhar urbano, o campo e os camponeses são analisados com pura descrição e vistos como arcaicos, inerente às ações promissoras e propulsoras do agronegócio e das indústrias, além de reafirmar a dicotomia urbano e rural, não os analisando como parte de um único processo histórico de apropriação, luta de classes e territorialização do capital no campo.

Segundo Floriano (2015),

O campo e a cidade, nos PCNs, são referenciados nessa temática numa visão setorial, numa abordagem dicotômica, em que pese no campo um ritmo de trabalho definido pelo tempo da natureza enquanto na cidade o tempo da natureza não apresenta tanta expressividade, logo é marcado pelo tempo mecânico. Considerar o tempo da natureza como definidor do ritmo de trabalho no campo, de forma generalizada, é desconsiderar os processos de difusão do meio técnico-científico-informacional e da complexificação nas relações campo-cidade. (FLORIANO, 2015, p. $120)$.

Assim, os documentos que regem a educação brasileira, em suas mais diversas escalas, fogem das abordagens da luta de classes, uma vez que salienta a figura do indivíduo (FLORIANO, 2015) e não do coletivo, mas embasados em ideias neoliberais, pois o desenvolvimento competitivo é a matriz de tudo, legitimados pelo falso discurso da ciência neutra.

Quanto ao transporte escolar, as queixas nas escolas foram muitas. A situação é de longe a pior no distrito de Arapuá, haja vista que falta manutenção nos ônibus (Figura 6) e em casos de tempo chuvoso, a dificuldade é aumentada. As estradas são danificadas pelas carretas que transportam eucalipto, interditando o acesso dos moradores ao distrito Arapuá ${ }^{5}$ Em 2015, uma comissão de mães de alunos de Garcias e de Arapuá denunciou as situações precárias do transporte escolar, oferecendo riscos a vida dos alunos. ${ }^{6}$ 
As contradições do cerceamento das políticas públicas para a educação do campo em Três Lagoas (MS):

Escola Estadual Afonso Francisco Xavier Trannin e

Escola Municipal Profa. Elma Garcia Lata Batista
Francielle Rodrigues de Macedo Sanches Sedeval Nardoque

Figura 6 - Três Lagoas (MS): falta de manutenção nos ônibus escolares públicos

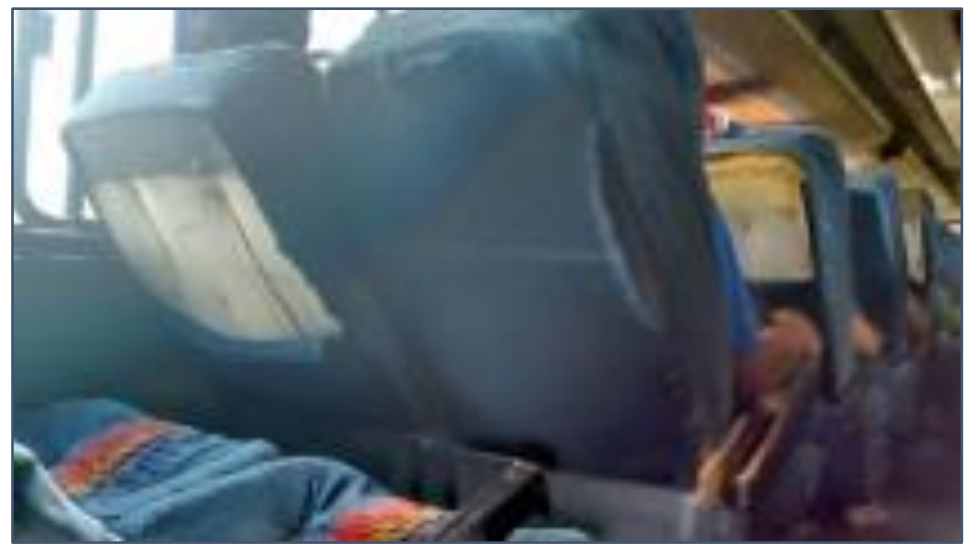

Fonte: www.arapuáms.com.br. 11, dez. 2015.

Logo o artigo 15, inciso II da resolução $n^{\circ} 1$ de abril de 2002, não é cumprido, pois o mesmo preconiza aos professores e alunos o transporte. Ao analisar o Art. $8^{\circ}$ e Art. 10, da resolução $n^{\circ} 2$ de abril de 2008, os mesmos garantem transporte a professores e alunos com qualidade, implicando na conservação de veículos, inclusive as condições de estradas e vias. A escola atende alunos das fazendas próximas, do Assentamento 20 de Março (no caso do distrito de Arapuá), e cidade de Três Lagoas (muitos destes alunos são aqueles em que os pais perderam o emprego nas fazendas de criação de gado, alterando o uso da terra para plantios de eucaliptos, os alunos migraram para a cidade, mas retornam ao campo para as aulas).

No que se refere à importância da Educação do Campo, as opiniões dos entrevistados caracterizam bem o que se objetiva com o ensino de cada escola.

Segundo funcionário entrevistado da Escola Municipal Elma Lata Garcia Batista:

Hoje a educação do campo? Tenho dois pensamentos, né? Um em relação as crianças daqui em termos [...] de finança, né? Dos pais são precárias [...] é um ou outro que tem uma condição melhor... Então as crianças vêm à escola mesmo [...] se alimentam bem [...] A escola movimenta Garcias [...] A escola aqui é uma fonte de renda pra muitas famílias. (Entrevista realizada no dia 17, mai. 2016).

De acordo com a funcionária entrevistada da Escola Estadual Afonso Xavier Trannin:

A educação do campo é para fixar o homem no campo, mas eu acho que ela não tem validade nenhuma se a gente não conseguir ensinar esses valores [...]. Se a gente não tiver um incentivo apropriado pra fixar esse homem no campo. No meu ponto de vista é importante ele estudar, é importante fazer uma faculdade, mas pra depois ele voltar pra terra 
As contradições do cerceamento das políticas públicas para a educação do campo em Três Lagoas (MS):

Escola Estadual Afonso Francisco Xavier Trannin e

Escola Municipal Profa. Elma Garcia Lata Batista
Francielle Rodrigues de Macedo Sanches Sedeval Nardoque

dele e produzir alguma coisa a partir daquilo que ele aprendeu, né? $\mathrm{E}$ eu não sei assim, se a gente consegue atingir $100 \%$ desse objetivo por conta dessa falta de infraestrutura que a gente tem, né? Falta tudo na verdade, então precisa melhorar. (Entrevista realizada no dia 17, mai. 2016).

A legislação, quando não cumprida em algum de seus artigos, fere todo o texto legal, uma vez que estão articulados os artigos, assim, as práticas das escolas rurais aqui estudadas não estão em consonância com os dispositivos legais, a saber, são principalmente aqueles ligados a qualidade de ensino, responsabilidade social e respeito ao modo de vida no campo.

Assim, a não adoção de políticas públicas de acordo com a legislação, como a Resolução $\mathrm{n}^{\circ} 1$ de 2002 e Resolução nº 2 de 2008, deixam as escolas suscetíveis às práticas das empresas de papel e celulose pela não manutenção das escolas rurais, enfraquecendo a Educação do Campo. Essa dará lugar a uma nova forma de resistência no meandrar da territorialização do capital do setor de celulose: tornar-se escola do campo, mas não deixar de existir.

As dificuldades evidenciadas pela intensificação do plantio de eucalipto, e, a diminuição dos funcionários das fazendas, concretizaram em 2018, as previsões de Kudlavicz (2011) sobre fechamento da Escola Municipal Profa. Elma Garcia Lata Batista ${ }^{7}$.

Protestos foram feitos pelos moradores de $\mathrm{Garcias}^{8}$, alegando a inviabilidade do transporte dos alunos para outras escolas, mas a secretaria de educação alegava que precisaria de um número mínimo de 30 matrículas para funcionamento.

Considerações finais: As consequências do cerceamento das políticas públicas na Escola Estadual Afonso Francisco Xavier Trannin e Escola Municipal Profa. Elma Garcia Lata Batista

Como visto, a não efetivação da Resolução n ${ }^{\circ} 1$ de Abril de 2002, que dispõe sobre Diretrizes Operacionais para Educação Básicas nas Escolas do Campo e Resolução n² de Abril de 2008, que dispõe sobre Diretrizes Complementares, normas e princípios para o desenvolvimento de Políticas Públicas de atendimento da Educação Básica do Campo, acarreta na exclusão escolar, evidenciadas na queda dos números de matrículas dos anos 
As contradições do cerceamento das políticas públicas para a educação do campo em Três Lagoas (MS):

Escola Estadual Afonso Francisco Xavier Trannin e

Escola Municipal Profa. Elma Garcia Lata Batista
Francielle Rodrigues de Macedo Sanches Sedeval Nardoque

2010 a 2016 e entre as etapas da Educação Básica nas escolas públicas rurais de Três Lagoas. Os números denunciam (além da precariedade e descaso dos governos na garantia e realização dos direitos próprios para os sujeitos do campo), a exclusão do aluno camponês, o que pode culminar no fechamento das escolas no campo (caso da Escola Municipal Elma Garcia Lata Batista).

Analisando todo estradar metodológico percorrido, considera-se, primeiramente, que este artigo não é um fim em si mesmo e que a análise e críticas discorridas sobre a efetivação das leis para a Educação do Campo (principalmente a Resolução $n^{\circ} 1$ de Abril de 2002 e Resolução $n^{\circ} 2$ de Abril de 2008), analisadas nas práticas das escolas, foram feitas levando em consideração que foram conquistadas por meio da luta dos camponeses (as resoluções estão embasadas nos princípios para a Educação do Campo). As análises levaram em consideração também os princípios jurídicos de que os interesses particulares não devem se sobrepor aos públicos e da igualdade, cujos textos legais estão articulados e embasados, logo a não efetivação de um artigo, culmina na não realização de outros, dessa forma, não abrange toda a qualidade no ensino para o povo do campo assegurada nessas resoluções.

Explicados esses pontos, ao analisar os objetivos a priori do artigo, chegou-se ao resultado de que as escolas possuem seus PPPs falhos, os planejamentos e currículos que embasam as aulas são em sua maioria articulados ao ensino urbano, bem como os materiais didáticos.

Os direitos embasados para uma educação camponesa, foram quase nulos na realidade das escolas (Escola Municipal Elma Garcia Lata Batista e Escola Estadual Afonso Francisco Xavier Trannin). Apesar das resoluções possuírem os pilares da Educação do Campo, e serem resultados de uma luta dos camponeses constante por direitos, a falta de ação dos governos, ou seja, a falta da realização dessas leis transforma as escolas do campo em escolas no campo.

Considerando a importância da Educação do Campo e toda sua pedagogia em movimento, que serve para a resistência/resiliência/permanência das famílias camponesas na terra de trabalho, a não adoção de políticas públicas no território em Três Lagoas está atrelada ao cerco do capital e articulação sob a ótica ora neoliberal ora desenvolvimentista do governo aliançado às empresas do setor de papel e celulose: Fíbria e Eldorado Brasil. 
As contradições do cerceamento das políticas públicas para a educação do campo em Três Lagoas (MS):

Escola Estadual Afonso Francisco Xavier Trannin e

Escola Municipal Profa. Elma Garcia Lata Batista
Francielle Rodrigues de Macedo Sanches Sedeval Nardoque

As empresas, munidas das várias estratégias, buscam na "semente do diálogo" a antecipação dos conflitos, realidade do campo em Três Lagoas. Elas têm o poder econômico e midiático, pois o "Agro é tech. Agro é pop. Agro é tudo"9, embasadas nas falácias do desenvolvimento sustentável e harmonioso que busca atender as necessidades do local, se aproveitam da não efetivação das políticas públicas nas escolas no campo transformando-as, assim, em alvos para a tentativa de difusão dos seus discursos hegemônicos.

Em contrapartida, a (re)criação camponesa, os vínculos dos alunos com a terra de trabalho, o esforço dos professores em buscar melhorias na educação e a importância que tem as escolas estudadas nesse artigo para os distritos Arapuá e Garcias, representam a resiliência/resistência dos camponeses, mesmo que em escolas no campo e desnudam uma realidade não harmoniosa pregada pelos discursos hegemônicos do setor de celulose em Três Lagoas.

Projetos e parcerias da UFMS/CPTL com os camponeses, como o NEDET, buscam fortalecer a Educação do Campo, trabalhando para autonomia e formação/fortalecimento de base política dos camponeses em Três Lagoas e no Território do Bolsão. $\mathrm{O} 1^{\circ}$ e $2^{\circ}$ Encontro de Jovens camponeses do Bolsão (o segundo realizado na Escola Estadual Afonso Francisco Xavier Trannin) $)^{10}$ evidenciaram a resistência da comunidade escolar no distrito Arapuá em permanecer com a escola no campo. $\mathrm{Na}$ atual conjuntura política, resistir/permanecer como escolas no campo, mesmo que não se encontre nas escolas os pilares das leis para uma Educação do Campo, é uma forma de resiliência e de resistência.

No município de Três Lagoas, essas contra forças ao cerco do capital materializado no monocultivo de eucalipto das empresas do setor de celulose, refirmam que as escolas mesmo fragilizadas com a falta de efetivação de políticas para a Educação do Campo, constituem como entraves à territorialização total do capital.

\section{Notas}

\footnotetext{
${ }^{1}$ Vinculada à Igreja Católica.

${ }^{2} \mathrm{O}$ que é transmitido à maioria de humanidade é, de fato, uma informação manipulada que, em lugar de esclarecer, confunde. Isso tanto é mais grave porque, nas condições atuais da vida econômica e social, a informação constitui um dado essencial e imprescindível. Mas na medida em que o chega às pessoas, como
} 
As contradições do cerceamento das políticas públicas para a educação do campo em Três Lagoas (MS):

Escola Estadual Afonso Francisco Xavier Trannin e

Escola Municipal Profa. Elma Garcia Lata Batista
Francielle Rodrigues de Macedo Sanches Sedeval Nardoque

também às empresas e instituições hegemonizadas, é, já, o resultado de uma manipulação, tal informação se apresenta como ideologia (SANTOS, 2001, p. 39).

${ }^{3}$ Para saber mais: < http://www.sed.ms.gov.br/censo-escolar-6/>. Acesso em: 09, mar. 2017.

${ }^{4}$ As informações foram obtidas em trabalho de campo no dia 17 de maio de 2016, realizado na Escola Estadual Afonso Francisco Xavier Trannin (distrito Arapuá) e Escola Municipal Profa. Elma Garcia Lata Batista (distrito Garcias).

5 Para saber mais: <http://www.arapuams.com.br/em-garcias-moradores-pede-melhoras-em-condicoesreferente-a-colheita-da-eucaliptos/>. Acesso em: 29 mar. 2017.

${ }^{6}$ Para saber mais: <http://www.arapuams.com.br/midia-de-tres-lagoas-destaca-arapua-e-garcias-criancascorrem-risco-de-vida-no-transporte-escolar/>. Acesso em: 29 mar. 2017.

${ }^{7}$ A presente pesquisa foi realizada entre os anos de 2015 e 2016, por isso não identificou o fechamento da Escola Municipal Profa. Elma Garcia Lata Batista em 2018, havendo necessidade de atualização de informação.

8 Para saber mais: <http://www.arapuams.com.br/moradores-de-garcias-protestam-em-prol-de-escola/>. Acesso em: 18 mai. 2019.

${ }^{9}$ Propaganda da Rede Globo de Televisão no canal aberto sobre os "benefícios” do agronegócio: "Agro, a indústria-riqueza do Brasil”. Para saber mais: < https://www.youtube.com/watch?v=raUo-TYfbJ4>. Acesso em: 15 mar. 2017

${ }^{10}$ Para saber mais: <http://www.arapuams.com.br/escola-de-arapua-recebe-o-2o-encontro-da-juventudecamponesa-do-territorio-rural-do-bolsao/>. Acesso em: 29 mar. 2017.

\section{REFERÊNCIAS}

ARROYO, Miguel Gonsalez; FERNANDES, Bernardo Mançano. A educação básica e o movimento social do campo. Brasília, DF: Articulação Nacional Por Uma

Educação Básica do Campo, 1999. Coleção: Por uma Educação Básica do Campo, $\mathrm{n}^{\circ}$ 2.

BRASIL. Ministério da Educação; Secretaria de Educação Básica. Secretaria de Educação Continuada, Alfabetização, Diversidade e Inclusão; Secretaria de Educação Profissional e Tecnológica; Conselho Nacional da Educação; Câmara Nacional de Educação Básica; Consulta Referente as Orientações para o Atendimento da Educação do Campo. In: Diretrizes Curriculares Nacionais da Educação Básica. Brasília - DF, 2013. p. $286-297$.

BRASIL. Ministério da Educação; Secretaria de Educação Básica; Secretaria de Educação Continuada, Alfabetização, Diversidade e Inclusão; Secretaria de Educação Profissional e Tecnológica; Conselho Nacional da Educação; Câmara Nacional de Educação Básica. Diretrizes Operacionais para Educação Básica nas Escolas do Campo. In: Diretrizes Curriculares Nacionais da Educação Básica. Brasília - DF, 2013. p. $266-285$.

BRASIL. Senado Federal. Medida Provisória. Disponível em: < http://www25.senado.leg.br/web/atividade/materias/-/materia/126992>. Acesso em: 10 mar. 2017.

CALDART, Roseli Salete. Educação do Campo. In: Dicionário da Educação do Campo. - Rio de Janeiro, São Paulo: Escola Politécnica de Saúde Joaquim Venâncio, Expressão Popular, 2012. p. 257-265. 
As contradições do cerceamento das políticas públicas para a educação do campo em Três Lagoas (MS):

Escola Estadual Afonso Francisco Xavier Trannin e

Escola Municipal Profa. Elma Garcia Lata Batista
Francielle Rodrigues de Macedo Sanches Sedeval Nardoque

CALDART, Roseli Salete. Pedagogia do Movimento Sem Terra. 3 ed. São Paulo: Expressão Popular, 2004.

CALDART, Roseli Salete. Pedagogia do Movimento. In: Dicionário da Educação do Campo. - Rio de Janeiro, São Paulo: Escola Politécnica de Saúde Joaquim Venâncio, Expressão Popular, 2012. p. 546-553.

CAMACHO, Rodrigo Simão. Paradigmas em disputa na educação do campo. 2013. 809 f. (Tese de Doutorado). Universidade Estadual de São Paulo, Programa de PósGraduação em Geografia, Presidente Prudente. p. 315-410.

FLORIANO, Eliana Menossi da Silva. Relação Campo-cidade, currículo e abordagens no ensino de Geografia. 2015. 240 f. (Dissertação de Mestrado). Universidade Federal de Mato Grosso do Sul, Programa de Pós-Graduação em Geografia, Três Lagoas. p. 94-133.

FREITAS, Waldélia Neves Dutra de. As Conquistas do Assentamento Santa Clara em Bataguassu/MS: A Luta Pela Educação no/do Campo. 2012. 156 f. (Dissertação de mestrado). Universidade Federal de Mato Grosso do Sul, Programa de Pós-Graduação em Geografia, Três Lagoas. p. 111-134.

HADDAD, Sérgio. Direito à educação. In: Dicionário da Educação do Campo. - Rio de Janeiro, São Paulo: Escola Politécnica de Saúde Joaquim Venâncio, Expressão Popular, 2012. p. 215-222.

JESUS, José Novaes de. A pedagogia da alternância e o debate da educação no/do campo no estado de Goiás. In: Revista NERA. Presidente Prudente. $N^{\circ}$ 18. 2011. p. 0720 .

KUDLAVICZ, Mieceslau. Dinâmica Agrária e a territorialização do complexo celulose/papel na microrregião de Três Lagoas/MS. 2011. 177 f. (Dissertação de Mestrado). Universidade Federal de Mato Grosso do Sul, Programa de Pós-Graduação em Geografia, Três Lagoas. p. 42-74.

KUDLAVICZ, Mieceslau; ALMEIDA, Rosemeire Aparecida de; Abrindo caminhos para uma educação que valoriza os saberes do homem e da mulher do campo. In: Educação no/do Campo em Mato Grosso do Sul. Campo Grande - MS. Ed. UFMS, 2008. p. $21-42$.

LEHER, Roberto. MOTTA, Vânia Cardoso. Políticas Educacionais Neoliberais e Educação do Campo. In: Dicionário da Educação do Campo. - Rio de Janeiro, São Paulo: Escola Politécnica de Saúde Joaquim Venâncio, Expressão Popular, 2012. p. 576-584.

LEMES, Glaucia dos Santos. NARDOQUE, Sedeval. Educadores do campo: diversidades e desafios diante do eixo temático terra, vida e trabalho no ensino 
As contradições do cerceamento das políticas públicas para a educação do campo em Três Lagoas (MS):

Escola Estadual Afonso Francisco Xavier Trannin e

Escola Municipal Profa. Elma Garcia Lata Batista
Francielle Rodrigues de Macedo Sanches Sedeval Nardoque

fundamental I. In: Revista Eletrônica da Associação dos Geógrafos Brasileiros Seção Três Lagoas-MS. $n^{\circ}$ 24, ano 13. 2016. p. 132-150.

LEMES, Mariana Santos. Territorialização do capital e as contradições da educação do campo na microrregião de Três Lagoas (MS). 2014. 175 f. (Dissertação mestrado) - Universidade Federal de Uberlândia, Programa de Pós-Graduação em Geografia. Uberlândia.

MARTINS, José do Souza. O poder do atraso. Ensaios de Sociologia da História Lenta. São Paulo, Hucitec, 1994.

MEDEIROS, Jociene Rosa de. EDUCAÇÃO NO/DO CAMPO: os jovens camponeses estudantes e as transformações ocorridas nos últimos anos na região de Arapuá. 2014. 18 f. (Trabalho de Conclusão de Curso) - Universidade Federal de Mato Grosso do Sul, Programa de Pós-Graduação LATO SENSU EM EDUCAÇÃO BÁSICA DO CAMPO. Três Lagoas - MS.

MOLINA, Mônica Castagna. FREITAS, Helana Célia de. Avanços e desafios na construção da educação do campo. Disponível em: <

http://emaberto.inep.gov.br/index.php/emaberto/article/view/2483/2440>. Acesso em: 02 de Fev. 2017.

MOLINA, Mônica Castagna. Legislação Educacional do Campo. In: Dicionário da Educação do Campo. - Rio de Janeiro, São Paulo: Escola Politécnica de Saúde Joaquim Venâncio, Expressão Popular, 2012. p. 451-457.

MOLINA, Mônica Castagna. Políticas Públicas. In: Dicionário da Educação do Campo. - Rio de Janeiro, São Paulo: Escola Politécnica de Saúde Joaquim Venâncio, Expressão Popular, 2012. p. 585-594.

NARDOQUE, Sedeval. ALMEIDA, Rosemeire Aparecida de. Território Rural do Bolsão (MS): Realidade e perspectivas. In: Boletim DATALUTA. $\mathrm{n}^{\circ}$ 85. 2015.

NARDOQUE, Sedeval. MELO, Danilo Souza. A questão agrária e indígena em Mato Grosso do Sul. In: Boletim DATALUTA. nº 97. 2016.

NARDOQUE, Sedeval. O campo e a cidade no ensino de Geografia e a realidade na Escola Rural São Joaquim, Selvíria (MS). In: A práxis no chão do assentamento. Ed. UFMS: Campo Grande, 2015.

A relação campo-cidade: abordagem sob o prisma da questão agrária. In: SPOSITO, Eliseu Savério et. al. A diversidade da Geografia brasileira: escalas e dimensões da análise e da ação. Rio de Janeiro: Consequência, 2016.

PONTIN, Vânia dos Santos. NARDOQUE, Sedeval. A Educação do/no Campo no Território Rural do Bolsão/MS: o caso da Escola Municipal Rural São Joaquim. In: 
As contradições do cerceamento das políticas públicas para a educação do campo em Três Lagoas (MS):

Escola Estadual Afonso Francisco Xavier Trannin e

Escola Municipal Profa. Elma Garcia Lata Batista
Francielle Rodrigues de Macedo Sanches Sedeval Nardoque

Revista Eletrônica da Associação dos Geógrafos Brasileiros - Seção Três LagoasMS. $\mathrm{n}^{\circ}$ 24, ano 13. 2016. p. 151-167.

RIBEIRO, Marlene. Educação Rural. In: Dicionário da Educação do Campo. - Rio de Janeiro, São Paulo: Escola Politécnica de Saúde Joaquim Venâncio, Expressão Popular, 2012. p. 293-299.

SANTOS, Milton. Por uma outra globalização: do pensamento único à consciência universal. 6 ${ }^{a}$ ed. Rio de Janeiro: Editora Record. 2001.

SECRETARIA DE EDUCAÇÃO DE MATO GROSSO DO SUL. Censo Escolar.

Disponível em: < http://www.sed.ms.gov.br/censo-escolar-6/>. Acesso em: 09 de mar. de 2017.

SILVA, Mariele de Oliveira. A (re)criação do campesinato em Cáceres/MT e no contexto de expansão territorial do agronegócio em Três Lagoas e Selvíria em Mato Grosso do Sul. 2014. 211 f. (Dissertação de Mestrado). Universidade Federal de Mato Grosso do Sul, Programa de Pós-Graduação em Geografia, Três Lagoas. p. 116175 .

TAFAREL, Celi Zulke. MOLINA, Mônica Castagna. Política Educacional e Educação do Campo. In: Dicionário da Educação do Campo. - Rio de Janeiro, São Paulo:

Escola Politécnica de Saúde Joaquim Venâncio, Expressão Popular, 2012. p. 576-585.

Recebido em 28/03/2018.

Aceito para publicação em 27/11/2018. 